Andrzej Rykała*

\title{
Institutional autonomy of Jews in Poland after World War II on the example of the cooperative movement
}

KEYWORDS: Jews, cooperatives, post-war period, the national-cultural autonomy SŁowa KLuczowe: Żydzi, spółdzielnie, okres powojenny, autonomia narodowo-kulturalna

\section{The conditions of creating the institutional autonomy for the Jews in Poland after World War II}

The Jews were in the first years after the Second World War the only national minority in Poland, who, in order to rebuild the foundations of biological and material existence, preserving their culture and traditions, and the expression of a broad spectrum of political concepts, created a form of institutional autonomy. Consent to the relative independence of the Jewish community from the government, which sought to build a single ethnically and free from the influence of religion society, had complex causes. They were embedded both in the dynamics of changes taking place on the international arena (especially in the Middle East), as well as the specifics of political transformations taking place in the country.

The course and consequences of the Second World War forced the international community to take a firm stand against the plans to create a Jewish homeland in the Middle East. Palestine, where the homeland was to arise, at the time was a politically unshaped area, with a significant strategic potential. Among others, the Soviet Union strived for subordination of this area, as the next outpost after the countries of Central and Eastern Europe. The country had a decisive influence on the Polish domestic policy as well. The concurrence of Soviet foreign policy interests and aspirations of the Jewish people to rebuild their own country had a significant impact on the approval of the Polish authorities on the relative autonomy and multifaceted activities of Polish Jews.

* Associate Professor, Department of Political, Historical Geography and Regional Studies Faculty of Geographical Sciences, University of Łódź. Mail: aaronbund@gazeta.pl. 
The Polish authorities also made use of the importance that the international environment attributed to the issue of the Jewish statehood. Striving - among others with the support of the Western Jewish communities - for international recognition and credibility of their government, those authorities gave Polish Jews permission for organizational autonomy and pluralism. It was to be a signal that the new Polish government was the only political force in the country interested in combating the postwar anti-Semitism.

Acceptance for a multiple and autonomous activities of the Jews was also the result of the rise to power of the pre-war opposition, trying to break with the nationalistic and clerical tradition, rooted among some of the old elites. Polish authorities gave their consent to a more liberal policy towards the Jewish minority also because of other factors. They were the need to prove the failure of the Nazi ideology, the possibility of receiving foreign aid to the devastated mentally and physically Jewish population, as well as the desire to redress the life and material losses suffered during the Second World War' ${ }^{1}$.

One of the forms of a multiple and relatively independent organizational activities of Polish Jews was (along with, among others, political parties, cultural and educational institutions), the cooperative movement ${ }^{2}$.

\section{Origins of the Jewish cooperative movement in Poland after the Second World War}

The creation of a separate cooperative movement for the Jews in Poland after the Second World War was primarily the result of the general situation in which this population was after the Holocaust, and the political changes taking place at that time in the country. Because of the plight of the Jews, the government authorities and representatives of the Jewish side had to adopt an immediate action to provide survivors with basic means of subsistence, as well as to create the concept of long-term economic policy. The so-called "productiveness" became a fundamental element of the new economic policy of the state. It was based on increasing the employment of the Jews (and not only) in the industry, the cooperative sector and farming. The responsible for the implementation of the program hoped for success, because its principles were to be applied to a small Jewish population (the over-one-million population of potential Jewish

1 J. Adelson, W Polsce zwanej Ludowa, [in:] Najnowsze dzieje Żydów w Polsce, J. Tomaszewski (edit.), Warszawa 1993, pp. 472-474; A. Rykała, Przemiany sytuacji społeczno-politycznej mniejszości żydowskiej w Polsce pod drugiej wojnie światowej, Łódź 2007, pp. 159-161.

2 A. Grabski, A. Rykała, Żydzi w Polsce 1944-2010, [in:] A. Grabski, A. Rykała, W. Sienkiewicz, J. Wijaczka, M. Wodziński, H. Zaremska, A. Żbikowski, J. Żyndul, Atlas historii Żydów polskich, Warszawa 2010, p. 395; A. Rykała, op. cit., p. 89. 
workers in the interwar period was placed as a point of reference for the difficulties in implementing similar plans) ${ }^{3}$. The support given to this concept by a large part of the Jewish community was also important for the adoption of the policy „of productiveness". The broad spectrum of political organizations representing it - referring to the views promulgated as early as at the end of the nineteenth century - were in favor of changing the current socio-professional structure of Polish Jews. The authorities tended to a situation where - as it was then claimed - „non-productive element” (merchants, manufacturers) would be replaced by a group of people „economically active”. The program of the new economic policy was to be used also to people without even any professional qualifications ${ }^{4}$.

The main initiator and coordinator of activities of productiveness was the Central Committee of Jews in Poland (CKŻP) - the largest and most important organization of Polish Jews, aspiring to represent them as a monopoly in relations with the Polish government and abroad - and on their behalf the Department of Productiveness ${ }^{5}$.

Special hope to improve the employment of the Jews was associated with the development of cooperative movement. The first Jewish cooperatives were organized at the beginning of 1945 . However, most of these institutions, due to financial and housing difficulties, were short-lived ${ }^{6}$. Another problem, the first cooperatives encountered, was the long period of waiting for favorable consideration of statements about the desirability of starting business by the state administration bodies (The Revisional Association). The source of the additional difficulty was the attitude of part of the Jewish population, whose unwillingness to work in cooperatives was due to the possibility of deriving income from various forms of individual work (in private workshops, trade, liberal professions).

The then political and economic conditions favored the development of the cooperative movement. Its guidelines, based on collective property, corresponded to the general concepts of the introduced process of socialization of the means of production. This meant that the position of the state authorities was generally favorable in relation to the development plan of the Jewish cooperative movement. Starting small forms of production and service activities (and the organized cooperatives were going to accept such a character) also gave the opportunity to find work quickly and improve

3 According to the author's findings, carried out on the basis of source materials, in mid-1946 there were almost 250 thousand Jews in Poland. See: A. Rykała, Przemiany..., pp. 26-46.

4 A. Rykała, Spółdzielczość żydowska w powojennej Polsce (1945-1949), „Acta Universitatis Lodziensis. Folia Geographica Socio-Oeconomica”, No. 6, Łódź 2005, p. 52.

5 Initially, relevant offices served this function, which in April 1946, as a result of the influx of repatriates from the Soviet Union, were converted into departments.

6 Jewish Historical Institute Archive (AŻIH), Central Committee of Jews in Poland (CKŻP), Department of Productiveness (WP), sign. 7, 159. Only 3 out of 6 cooperatives established in 1945 in Warsaw survived till the end of that year. 
the situation. Another factor in favor of the organization of the cooperative movement in the Jewish community was the psychological aspect. Initiating the development of a separate cooperative sector was an attempt to approach the progressive integration of the Jewish community as the group of the most vulnerable, without prospects in life, scared and resigned people 7 . Not without significance was the fact that many Jews had adequate professional training, acquired before the war in Poland or during the war while staying in the USSR.

The first cooperatives (mainly textile and clothing) were created in 1945 in Łódź, Łódź region, and in Białystok, Częstochowa, Kraków, Lublin, Przemyśl, Tarnoów, Warsaw, Radom, Katowice, and Dzierżoniów (Rychbach) ${ }^{8}$. At the end of this year 23 Jewish cooperatives operated, employing approx. 800 employees (out of approx. 7 thousand of all the Jews employed in the country $)^{9}$. They represented the following industries: tailoring (9 cooperatives), construction (3), electromechanical (3) and the food (2). The other six ones provided different services ${ }^{10}$ The largest number of cooperatives were in Łódź (9), and subsequently in Lower Silesia (4) Warsaw (3), Krakow (2), and in Bialystok, Czestochowa, Lublin, Tarnow and Sosnowiec (in each one) ${ }^{11}$.

In Łódź, the garment-underwear cooperative „Astra” represented high quality of services and relatively good financial condition. They produced workwear and children clothes. The cooperative was established in April 1945. It employed150 people. Among other cooperatives in Łódź there were also others in good condition: the tailor cooperative"Dom Modelowy" (founded in September 1945), providing high-quality services for the production of clothing for civilians and military personnel; furniture cooperative „Młot” (founded in June 1945, employing 30 workers), manufacturing

7 M. Grynberg, Żydowska spółdzielczość pracy w Polsce w latach 1945-1949, Warszawa 1986, p. 53.

8 AŻIH, CKŻP, Department of Registration and Statistics (WEiS), sign.122, 471; WP, sign. 159. In April of 1945, two cooperatives worked in Lodz: garment-underwear „Astra” and collecting rags ",Surowiec”. Cooperatives in Warsaw, Lublin, Lodz, Bydgoszcz, Czestochowa, Kielce, Katowice, Tarnow and Wloclawek were being organized. At the turn of April and May the cooperative movement consisted of following institutions: carpentry and mechanical plant "Arbar” and cooperative of electricians „Elektromechanika” in Warsaw; cooperatives „Astra”, „Surowiec”, the underwear cooperative with a laundry and dye-house „Opus”, the construction and repair cooperative „Remont” and transport cooperative „Trud” in Łódź; hand laundry in Lublin; the cooperative of hairdressers and cooperative of electro mechanics in Czestochowa; tailor cooperative and tricot cooperative in Cracow; garment-underwear cooperative in Tarnów. In many cities, they created many workshops in the form of companies, associations of several employees. They also conducted trainings preparing for employment in these institutions, which took place among others at the Weaving School in Warsaw (20 students) and cooperative „Astra” in Lodz.

9 AŻIH, CKŻP, WEiS, sign. 471; WP, sign. 43.

10 AŻIH, CKŻP, WP, sign. 43, 159, 160. Department of Productiveness also informed there were 20 cooperatives employing 755 workers at the end of 1945 . They were: 9 clothing cooperatives (451 employees), 3 construction (100), 3 electromechanical (108), 2 food (22) and 3 others (74).

11 AŻ̇H, CKŻP, WEiS, sign. 122, 471. 


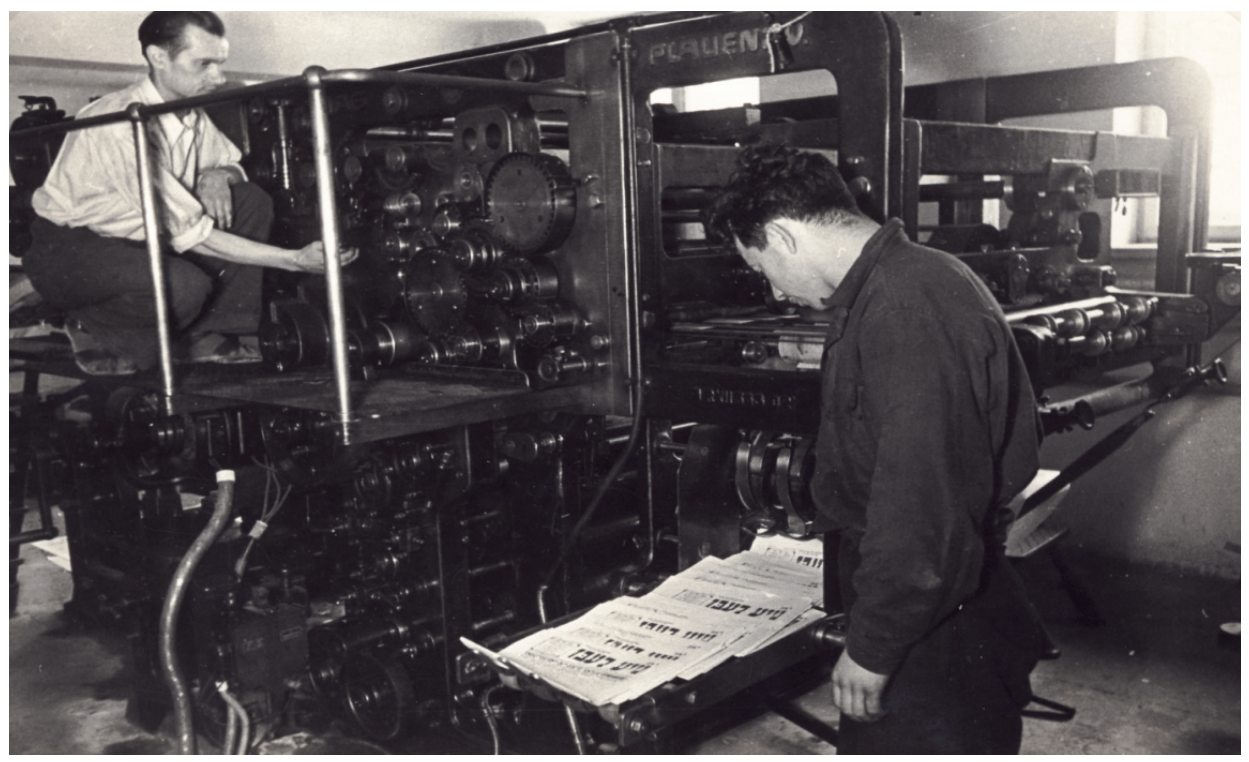

Photo 1. The newspaper printing-house Dos Naje Lebn (Łódź, 1946).

furniture and providing repair services in homes and offices; the cooperative of metal products „Metalowiec” (founded in June 1945, 30 employees), specializing in the repair of knitting machines and plumbing services; the publishing cooperative „Dos Naje Lebn” ( „New Life”), which employed 20 workers and issued the newspaper of the same name, and other publications in Yiddish (Photo 1$)^{12}$.

Although the first, small cooperatives were organized under the auspices of the Jewish Bund, the Socialist Party, CKŻP took over the main initiative in the appointment of the next ones ${ }^{13}$. In January 1946, the Committee took care of already 27 cooperatives where 733 Jews were employed ${ }^{14}$.

\section{Cooperatives as workplaces for the repatriates}

In the following months of 1946, there were more and more cooperatives. This increase resulted from the need to create new jobs for the Jewish repatriates arriving en masse from the Soviet Union. Many of these people had the appropriate qualifications to find employment in the organized cooperatives. Among them, there were tailors,

12 AŻIH, CKŻP, WP, sign. 120. There were also the tailor-underwear cooperative „Równość”, the tailor cooperative "Igła” the renovation-construction cooperative „Remont” and upholstery cooperative „Wygoda”.

13 Archives of New Records (AAN), WP, sign. 295/VII/149.

14 AŻIH, CKŻP, Presidium, sign. 303/5. 
Professions: with no profession craftsmans

workers

students

clerks

merchandisers

teachers and educaters

various

doctors

engineers

artists

lawyers

farmers

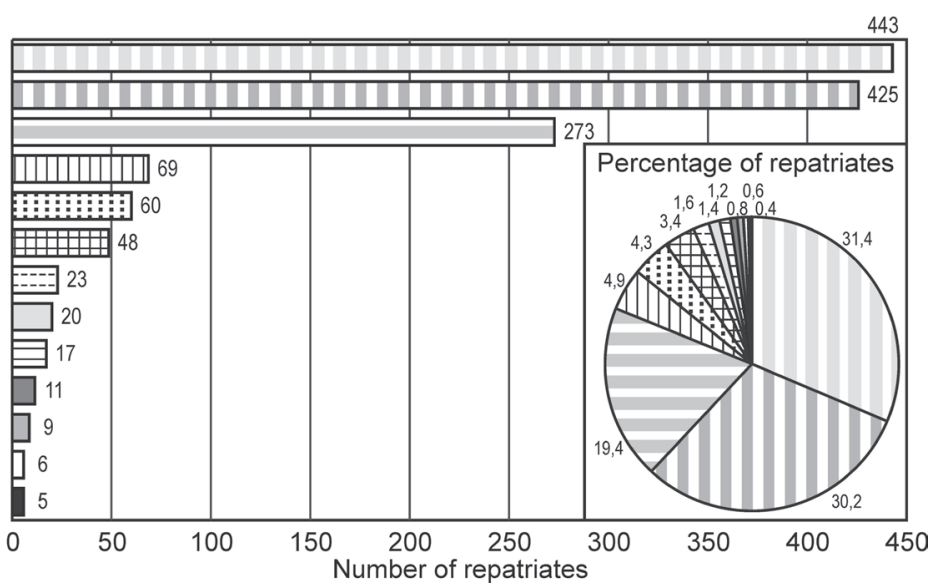

Fig. 1. Structure of professions of repatriates who came to the country in the first quarter of 1946 (Białystok, Częstochowa, Gdańsk, Lublin and Olsztyn). Source: own study.

shoemakers, shoe upper makers, carpenters and representatives of other professions useful for the development of the cooperative movement (Fig. 1) ${ }^{15}$.

Relatively large arrival of Jews in Lower Silesia meant that the local Provincial Jewish Committee (WKZ - a district branch of CKŻP) undertook intensive efforts to organize new cooperatives ${ }^{16}$. The situation in the Western Territories, which Poland took over after the Second World War from Germany, heavily favored that. An important prerequisite for the creation of cooperative institutions was easy to obtain appropriate equipment in the form of premises and machines from the government and local authorities. In addition, under the policy of managing these lands, declarations of advisability of starting the cooperative businesses were examined on an expedited procedure. At the end of January 1946, so before the arrival of the first mass wave of repatriates, approx. 10 cooperatives functioned in Lower Silesia, mainly in Dzierżoniów (including the tailor cooperative „9 Maja”) and Wałbrzych (among others underwear-tailor and locksmith-mechanical cooperatives ${ }^{17}$.

15 AŻIH, CKŻP, WP, sign. 43.

16 Both Jewish repatriates from the USSR, as well as Jews from other Polish lands flooded to the areas abandoned by the German population, especially in the Lower Silesia and Szczecin. Besides the improvement of the material conditions, the decision of the change of the settlement was taken on the basis of among others: safety (weakness of the organizations which used in their underground struggle policy of anti-Semitism and the lack of anti-Jewish actions resulting from increased decomposition of social ties), psychological (need to live in larger Jewish groups), and even tactical (settlement in the border areas favored illegal, in part tolerated by the authorities, emigration from Poland).

${ }_{17}$ AŻIH, CKŻP, WP, sign. 8, 43. 


\section{Support and coordination of the Jewish cooperative movement - Fund for Productiveness of Jews and the Head Office of Factory and Consumer Cooperatives "Solidarność"}

Two institutions had a significant impact on the organization of the Jewish cooperativeness and coordination of actions undertaken by individual units. One of them was, formed on 15 January 1945 by CKŻP, the Fund for Productiveness of Jews (KSPŻ), of which primary task was to provide low-interest loans to cooperatives and individual plants. The creation of the second one was to organize the internal organization of the cooperative movement, to improve the delivery and sale of finished products and to develop a program for the development of new cooperatives. To accomplish these tasks CKŻP set up a central organization for Jewish cooperatives. The Head Office of Factory and Consumer Cooperatives "Solidarity" (CSWiK "Solidarność") initiated its operations on 21 February $1946^{18}$. According to the adopted articles of the association, the main objective of the organization was „economic support of cooperatives associating persons submitted to CKŻP, and created for commercial employment of these people”19. In this way, the activity of CSWiK „Solidarność" was confined to the implementation of the program of CKŻP in employing Jewish people ${ }^{20}$. In April 1947, CSWiK was transformed within the organization of its internal structure. The change in the statute concerned, among others, the establishment of local self-government bodies. Further changes concerning the powers of CSWiK, were associated with subsequent amendments in the charter ${ }^{21}$, approved in July $1948^{22}$. The transformations, which the internal structure of the Jewish cooperativeness was subject to, formed part of a broader approach designed to bring order to the whole organization of the cooperative movement in Poland. Along with these decisions the name of CSWiK was changed. Since July 1948 it was: The Head Office of Factory Cooperatives „Solidarność”

18 AAN, sign. 295/VII/149.

19 AŻIH, CKŻP, WP, sign. 161. Charte of CSWiK „Solidarność”.

20 In 1946 there were three economic head offices, uniting cooperatives: Economic Head Office of Productive Labor Cooperative (based in Warsaw), Central Industrial Cooperative Union (based in Łódź) and Head Office of Factory and Consumer Cooperatives (in Warsaw).

21 The charter of the Head Office from the very beginning assumed that all the cooperatives organized by the Jewish community (i.e. the labor, service, auxiliary and commercial cooperatives) would belong to the HO. In June 1948, the Supreme Council of Cooperatives took steps to reorganize the cooperative movement in the country. As a result of these measures cooperative economic head offices of a specific industry-focused and activity profile were established. In this way, there was a transfer of these cooperatives, between the head offices, which due to the nature of the business did not fit the profile of action of each head office. As a result of these activities, in 1948, there were only two head offices: the Head Office of Labor Cooperatives and the Head Office of Productive Cooperatives „Solidarność”.

22 M. Grynberg, op. cit., pp. 62-63. 
(CSW „Solidarność"). The final act of functioning of the Head Office, as a separate institution grouping Jewish cooperatives, was the connection with the Head Office of the Cooperatives (CSP) at the end of 1949.

\section{In the context of Kielce pogrom - development of the Jewish cooperative movement in 1946}

Starting from 1946 the Jewish cooperative movement was characterized by dynamic growth. They created new cooperatives and increased the number of employees. The upward trend was not halted even by mass emigration of Polish Jews in the second half of 1946, which was largely the result of the pogrom perpetrated against the Jewish population in Kielce on 4 July of that year. At the end of 1946, 86 Jewish cooperatives worked in Poland, of which 48 were under the care of a local branch of CSWiK in Wrocław, 17 of a local branch in Łódź, while the local branches in Katowice, Szczecin and Warsaw had seven cooperatives each ${ }^{23}$. The number of workers employed in them was proportional to the number of cooperatives associated in each branch, e.g. in Wrockaw there were 985 people, in Łódź - 419, Katowice, Szczecin and Warsaw - 172 each (Fig. 2).

In the period of general chaos that prevailed among the Jews in connection with the Kielce pogrom, the Jewish cooperative movement suffered, in comparison with other sectors of the economy, the smallest loss caused by decrease of the number of employees. Many Jews left state-owned enterprises and moved to the newly-launched cooperative institutions. They provided an increased safety arising from work among those derived from the same ethnic environment. Moving to the cooperatives was caused by the relatively higher wages that the workers of these cooperatives earned, compared with employed in the state institutions (including, among others, a hundred miners who moved from a mine to the cooperatives in that period) ${ }^{24}$.

Regular departures of Polish Jews did not remain without impact on the structure of employment in the Jewish cooperative sector. The people of Polish nationality gradually replaced emigrating Jewish workers (e.g. in Szczecin employees of cooperatives identifying with the Jewishness constituted less than half of the staff in November 1946 - Fig. 3).

23 AŻIH, CKŻP, WP, sign. 47., State Archive in Łódź (APŁ), Presidium of National Council (PRN), Office of Internal Affairs (USW), sign. 2357. There were 20 cooperatives in Łódź in 1946, employing 570 workers. Due to financial problems, 3 of them ceased to exist.

24 AAN, sign. 295/VII/149. 

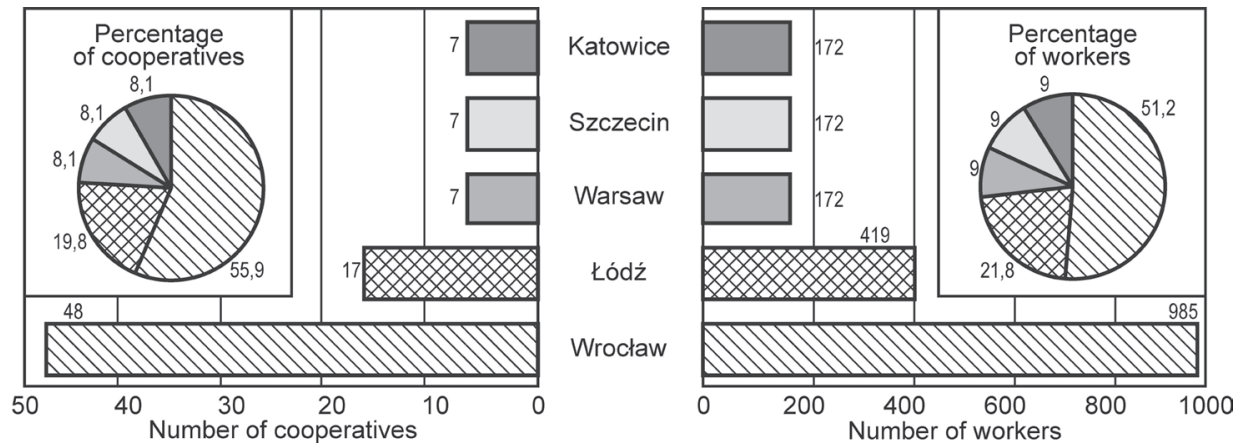

Fig. 2. Number of cooperatives and their employees by local branches CSWiK „Solidarność” in 1946. Source: own study.
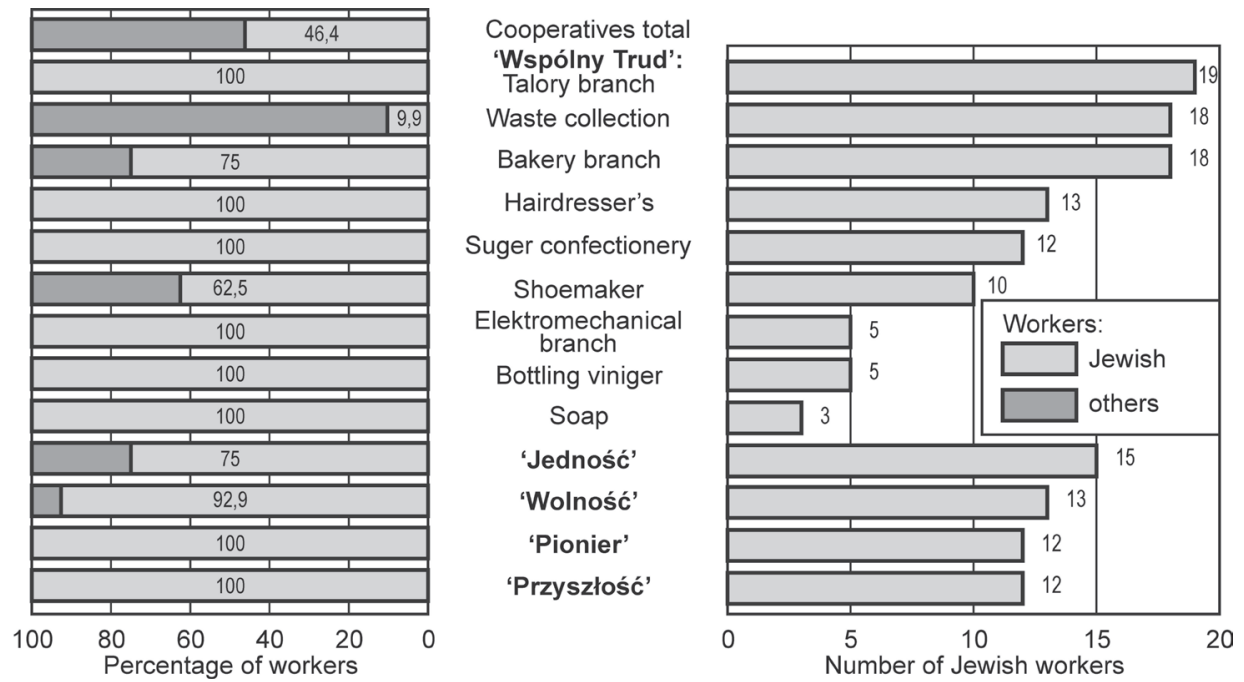

Fig. 3. Number and ethnic identification of workers employed in the Szczecin cooperatives (as of 1 November 1946). 


\section{Institutional measures for the stabilization and normalization of the economic situation of Polish Jews - the Government's Commissariat for Productiveness of Jewish Population and the Development Organization of Industry, Crafts and Agriculture Business}

In the second half of 1947, there was a relative stabilization of the economic situation of the Jewish population. The beginning of activities of two institutions had a big impact on achieving it. One of them was, created in July 1945, the Government's Commissariat for Productiveness of Jewish Population (KRSPLŻ), subject to the Presidium of the Council of Ministers (PRM). The basis of the activities of the Commissariat was local branches at the provincial offices operating in major Jewish settlements ${ }^{25}$. The Commissariat worked on employment, safety and emigration of the Jews. Due to the progressive normalization of socio-economic situation of this minority, in October 1947, the mentioned governmental body stopped working, and some of its existing competences were taken over by the departments of internal affairs of the relevant provincial authorities ${ }^{26}$. Another institution with a strong record of accomplishment in the productiveness field was the Development Organization of Industry, Crafts and Agriculture Business among the Jewish population in Poland (ORT). It dealt mainly with vocational training of Jews and organizing farms for them.

\section{Development of the Jewish cooperative movement in the years 1946-1949 - the branch structure, the number of branches and employees}

In the context of ongoing stabilization and normalization, the Jewish cooperative movement also reached effective development. Good economic performance of many cooperatives and the ability to work "among their own compatriots" meant that many Jews tried to take employment in this sector. To meet this demand, CSWiK expanded the old and organized the new facilities. As a result, 143 Jewish cooperatives with 3,300 employees functioned in January $1947^{27}$. Most people were employed in cooperatives in Lower Silesia - 1626, in Łódź - 625, Szczecin - 410, Kraków - 222, in Upper

25 APŁ, Provincial Office in Łódź (UWŁ), sign. 240.

26 Ibidem.

27 AŻIH, CKŻP, WP, sign. 155, 160. At the beginning of 1947 there were 143 cooperatives: 44 tailor ones, 4 tailor-shoemaker, 22 shoemaker, 4 construction, 1 electromechanical, 12 locksmith-mechanical, 5 hairdresser, 3 indoor painting, 3 textile, 7 transport, 1 radio technical, 8 food industry, 10 carpentry, lupholstery, 3 bristle-brush, 4 leather-fancy goods, 1 production of cotton wool and quilts, 2 publishing, 1 soap, 1 fishing, 1 hat-making, 2 waste-collecting, 2 photographic, and a cooperative of various kinds of activities. 
Tab. 1. The number of cooperatives by industry in geographic terms May 1947

\begin{tabular}{|c|c|c|c|c|c|c|c|c|}
\hline 莺 & 离 & 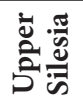 & 岕 & 式 & 递亭 & 咅尝 & 离: & 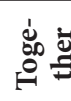 \\
\hline Tailor & 24 & 6 & 4 & 11 & 1 & 1 & 5 & 52 \\
\hline Shoemaker & 16 & 1 & 2 & 2 & - & 1 & 2 & 24 \\
\hline $\begin{array}{l}\text { Locksmith - } \\
\text { mechanical }\end{array}$ & 5 & 2 & 1 & 1 & 1 & - & 1 & 11 \\
\hline Transport & 4 & - & 1 & 1 & - & - & - & 6 \\
\hline \begin{tabular}{|l|}
$\begin{array}{l}\text { Carpenter- } \\
\text { construction }\end{array}$ \\
\end{tabular} & 6 & 1 & 2 & 3 & 1 & 1 & - & 14 \\
\hline Bristle-brush & 3 & - & - & - & - & - & - & 3 \\
\hline $\begin{array}{l}\text { Leather- } \\
\text { fancy goods }\end{array}$ & 2 & - & - & 1 & - & - & - & 3 \\
\hline Chemical & - & 1 & - & - & - & - & - & 1 \\
\hline Electromechanical & - & - & - & - & - & 1 & - & 1 \\
\hline Bakery & 3 & - & 1 & - & - & - & 1 & 5 \\
\hline Plant & - & - & 1 & - & - & - & - & 1 \\
\hline Weaving & - & - & - & 2 & - & - & - & 2 \\
\hline Textile & - & - & - & 1 & - & - & - & 1 \\
\hline Hosiery & 5 & - & - & - & - & 1 & - & 6 \\
\hline Various & 16 & 4 & 8 & 4 & 1 & 1 & - & 34 \\
\hline Together & 84 & 15 & 20 & 26 & 4 & 6 & 9 & 164 \\
\hline
\end{tabular}

Source: AŻIH, CKŻP, WP, sign. 160.

Silesia - 207 and in Warsaw - 106. 104 employees altogether worked in the other institutions. In May 1947, the number of cooperative institutions increased to 164 and the number of employees - up to 3955 (Table. 1).

203 Jewish cooperatives employing 5212 workers functioned in October 1947. Among them 30 cooperatives (14.8\%) were the major economic units (each employing several dozen people), with 2,568 employees ( $49.3 \%$ of total employment in the cooperative sector), while 173 units (85.2\%) were small cooperatives, where 2,664 people worked $(50.7 \%)^{28}$.

In 1948 the number of cooperatives decreased and at the end of this year and in the first quarter of 1949 there were 178 units (of a total of 778 cooperatives in the country), employing 9244 workers (Fig. 4) ${ }^{29}$.

\footnotetext{
28 AŻIH, CKŻP, WP, sign. 83.

29 AŻIH, CKŻP, WP, sign. 148.
} 


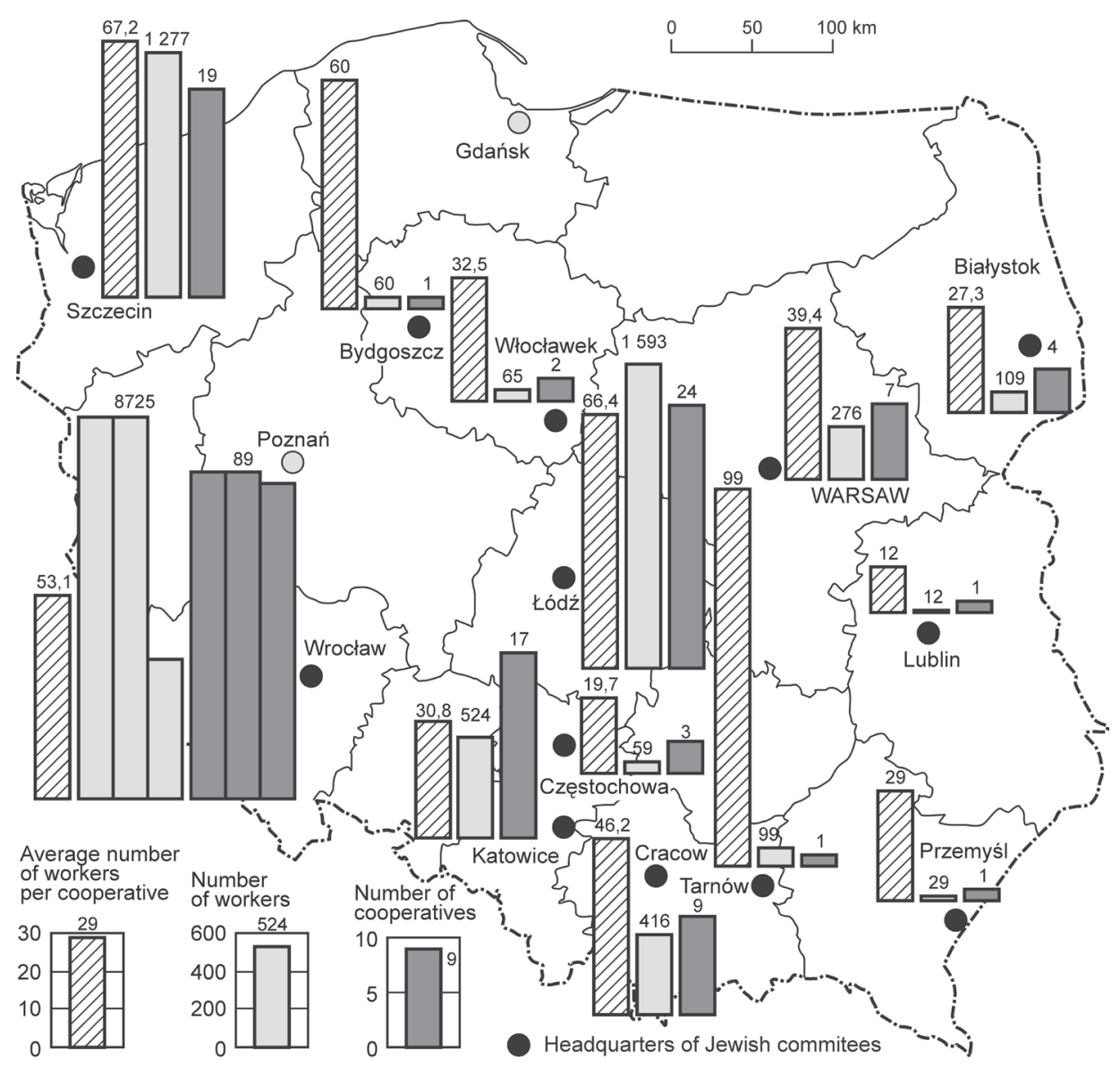

Fig. 4. Jewish cooperatives in the first quarter of 1949

Because of the liquidation of less profitable cooperatives, combining those of a similar production profile and handing over - as part of the reorganization of the cooperative movement in Poland - some units to CSW, the number of cooperatives fell to 166 in October 1949. Fifty cooperatives merged in the years 1948-1949. In 1948, in connection with the reorganization of the cooperative movement and the creation of a branch system of head offices, CSW „Solidarność” gave CSP 18 cooperatives of which production profile did not suit the character of the specific branch (e.g. forwarding and transport, butchery, food, settlement- lotting). 

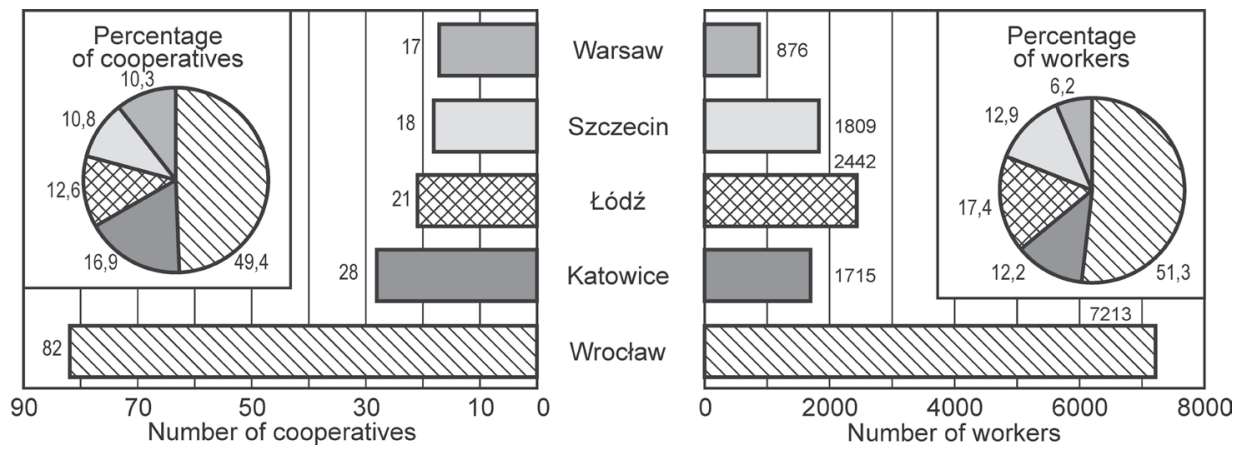

Fig. 5. Cooperatives and the number of employees in regional branches of CSW „Solidarność” (as of 31October 1949).

The 166 cooperatives working in October 1949 employed 14055 people $^{30}$. The drop in the number of units, compared to the beginning of that year, was accompanied by increase in the employment levels. The main reason for this situation was the influx of workers of Polish nationality to the Jewish cooperatives. In part, they replaced the former staff who took part in the mass departure of Jews from Poland.

In 1949, more than $50 \%$ of employees in cooperatives worked in Lower Silesia. The cooperative sector in Łódź owned a relatively high representation (17.4\%). In Lower Silesia, there were also the majority of cooperatives (nearly 50\%). Later, however, the highest number of units were organized in Upper Silesia (16.9\%, although in terms of the number of employees this area was lower in rank than Wrocław, Łódź and Szczecin) and next in Łódź (12.6\%), Szczecin (10.8\% ) and Warsaw (10.3\%) (Fig. 5).

In the years 1945-1949 a total of 232 Jewish cooperatives were created (most of them in the area of Lower Silesia). In 1946, those facilities accounted for $55.9 \%$, and in October 1949 - 49.4\% of all Jewish cooperatives operating in the country (Fig. 2 and 5). They contributed not only to the professional activation of the Jewish population of the region, but became an important and permanent part of managing these lands as well. In the middle of 1946 Jewish cooperatives in the region Szczecin and the Lower Silesia accounted for $81 \%$ and $95 \%$ of all cooperatives operating there ${ }^{31}$.

\footnotetext{
30 M. Grynberg, op. cit., p. 75.

31 AŻIH, CKŻP, WP, sign. 83.
} 
Tab. 2. Number of cooperatives and employees in industries

\begin{tabular}{|l|c|r|r|r|}
\hline \multicolumn{1}{|c|}{ Industry } & $\begin{array}{c}\text { Number of } \\
\text { cooperatives }\end{array}$ & \multicolumn{1}{c|}{$\%$} & $\begin{array}{c}\text { Number of } \\
\text { employees }\end{array}$ & \multicolumn{1}{c|}{$\%$} \\
\hline Tailor & 52 & 31,7 & 1781 & 45,0 \\
\hline Footwear and leather & 24 & 14,6 & 451 & 11,4 \\
\hline Carpentry- construction & 14 & 8,5 & 262 & 6,6 \\
\hline Locksmith --mechanical & 11 & 6,7 & 263 & 6,6 \\
\hline Transport & 6 & 3,7 & 105 & 2,7 \\
\hline Hosiery & 6 & 3,7 & 152 & 3,9 \\
\hline Bakery & 5 & 3,0 & 121 & 3,1 \\
\hline Leather- fancy goods & 3 & 1,9 & 39 & 1,0 \\
\hline Bristle-brush & 3 & 1,9 & 106 & 2,7 \\
\hline Weaving & 2 & 1,2 & 28 & 0,7 \\
\hline Textile & 1 & 0,6 & 36 & 0,9 \\
\hline Factory & 1 & 0,6 & 204 & 5,2 \\
\hline Chemical & 1 & 0,6 & 12 & 0,3 \\
\hline Elektromechanical & 34 & 20,7 & 385 & 0,2 \\
\hline $\begin{array}{l}\text { Others (upholstery, hairdresser, } \\
\text { photographic) }\end{array}$ & 164 & 100,0 & 3955 & 100,0 \\
\hline Together & & & & \\
\hline
\end{tabular}

Source: AŻIH, CKŻwP, WP, sign. 160.

The tailor industry dominated - taking into account the number of cooperatives and employees - in the industry structure. In May of 1947, tailor cooperatives, employing $45 \%$ of the total number of employees, accounted for $31.7 \%$ of all cooperative institutions (Tab. 2) ${ }^{32}$. Dominant participation of units offering this type of services in the industry structure was due to on the one hand an objective necessity, on the other hand conscious organizational moves ${ }^{33}$. In the occupational structure of the Jewish population, there was quite a large share of the pre-war tailors, who in the initial stage of the formation of the cooperative movement could to join the work immediately. A large number of personnel and the relatively high level of their services made tailoring the flagship industry of the Jewish cooperatives. The technical equipment of sewing cooperatives also had great influence on its dynamic development that was richer in

32 AŻIH, CKŻP, WP, sign. 160.

33 AŻIH, CKŻP, WP, sign. 155. In 1946 representatives of many cooperatives accused the authorities of CSWiK „Solidarność" that they favored the tailor-shoemaker cooperatives (e.g. "Wspólny Trud" in Szczecin, "Zgoda" and "Trud" in Lower Silesia and "Jedność" and "Zakord" from Łodzi), providing them with the majority of orders and assignments. Other institutions, especially those that were distant from the center of the country, received - claimed as part of the cooperative - a much smaller number of orders. This situation contributed to the crisis of many cooperatives and caused a break in the continuity of activity (e.g. in the case of cooperative "Salon Mód" from Białystok). 
comparison with other industries (a large part of used machines and tools came from the cooperative members or donations coming from foreign Jewish institutions). In addition, a great demand for necessities, which tailoring products were after the war, made of tailoring the fastest growing industry.

In the industry system, footwear and leather services, having also a long professional tradition among Jews, were represented in a great number. In May 1947 this branch was represented by 24 cooperatives ( $14.6 \%$ of all members of the Jewish cooperative movement), employing 451 people (11.4\% of the total workers of Jewish cooperativeness). Further, due to the number of cooperatives and workers in their employment, there were such branches as carpentry and construction, having 14 institutions (8.5\%) with 262 employees (6.6\%) and the Locksmith --mechanical - 11 cooperatives $(6,7 \%)$ with 263 workers $(6.6 \%)$.

\section{Conclusions}

Changes in Polish politics and economy, which developing Stalinism began in 1948 (among others strict control of all areas of life by mono-party system, the development of an economy based on central planning of investments and central distribution of goods, the emphasis on heavy industry), were reflected in the activities of the Jewish cooperatives. Arranging the entire cooperative movement in Poland (involving the liquidation of the unprofitable cooperatives, merging institutions of similar production profile and passing cooperatives that did not suit the branch nature of the CSW "Solidarność" to CSP) was associated with closer supervision of state authorities over the Jewish cooperatives and making attempts to merge them with the other Head Office. The steps to unite the cooperative movement were the realization of proclaimed slogans by the state authorities on the single society, united by the affirmative attitude towards the ongoing political changes. The existence of separate economic structures, separated on the basis of ethnic criteria, were certainly not consistent with these demands. Changes in the Jewish cooperative movement were accelerated, due to legal and illegal emigration, by the declining steadily number of employees of Jewish origin. The consent of state authorities for legal emigration of Jews to Israel and other countries in Europe, which happened from 1 September 1949 to 31 August 1950 (and then to the beginning of 1951), contributed to the further depletion of the ranks of cooperative members. Prospects for the "productive" development of Jewish cooperatives decreased in this situation. The influx of workers of Polish nationality, whose number grew steadily, put into question the legitimacy of the existence of an autonomous economic division created on the basis of ethnic criteria. Therefore, the concept 
of integration of the entire cooperative movement in Poland arose among the state authorities. United and deprived of ethnic divisions the cooperative sector was to revive the activities of each cooperative in the wide range of providing services, increasing the production of goods and the creation of new jobs in line with the planned economic policy of the state. The unification of the two cooperative head offices The CSW and CSW "Solidarność" took place at a joint Congress of Delegates of 11 December 1949. The new head office was renamed the Union of Work Cooperatives.

In summary, we can conclude that operating under a separate cooperative-sector institutions contributed significantly to the economic revival of the Jewish population. Especially, in the first period after the war, the development of the Jewish cooperative movement led to the improvement of the material situation of the Jews and helped them adapt to normal life. Starting work in cooperative institutions was for many Jews the main argument in favor of staying in Poland. For many people, especially of the more left-wing attitude, the organization of the cooperative movement in their own environment was the national implementation of the pre-war ideas. Jewish cooperatives were also of important psychological significance. Indeed they allowed to unite in a common effort the victims cruelly experienced by war. This significantly contributed to the integration of the environment of Polish Jews. Jewish cooperatives were an important element of the organization of economic life and an essential factor for economic revival of the country, mainly in the Western Lands.

\section{Bibliography}

Adelson J., W Polsce zwanej Ludowa, [in:] Najnowsze dzieje Żydów w Polsce, J. Tomaszewski (edit.), Warszawa 1993.

Grabski A., Rykała A., Żydzi w Polsce 1944-2010, [in:] A. Grabski, A. Rykała, W. Sienkiewicz, J. Wijaczka, M. Wodziński, H. Zaremska, A. Żbikowski, J. Żyndul, Atlas historii Żydów polskich, Warszawa 2010.

Rykała A., Przemiany sytuacji społeczno-politycznej mniejszości żydowskiej w Polsce pod drugiej wojnie światowej, Łódź 2007.

Rykała A., Spółdzielczość żydowska w powojennej Polsce (1945-1949), „Acta Universitatis Lodziensis. Folia Geographica Socio-Oeconomica", No. 6, Łódź 2005. 


\title{
Institutional autonomy of Jews in Poland after World War II on the example of the cooperative movement
}

\author{
ABSTRACT
}

The article presents the origins, development and liquidation of the Jewish cooperative movement in Poland after the Second World War. It outlines the socio-political background, which contributed to the creation of a kind of national-cultural autonomy for the Jews, including one of its pillars - the cooperative movement. The functioning of cooperative institutions was analyzed for the structure of the industry, distribution and their number, and the number of workers employed there. I also assessed the role that their own cooperatives played in the reconstruction of post-war life of the Jewish population in Poland, both in the material as well as social and psychological fields, and also in the development of the cooperative movement in general.

\section{Autonomia instytucjonalna Żydów w Polsce po drugiej wojnie światowej na przykładzie ruchu spółdzielczego}

STRESZCZENIE

W artykule przedstawiono genezę, rozwój i likwidację żydowskiego ruchu spółdzielczego w Polsce po drugiej wojnie światowej. Nakreślono uwarunkowania społeczno-polityczne, które przyczyniły się utworzenia swoistej autonomii narodowo-kulturalnej dla Żydów, w tym jednego z jej filarów spółdzielczości. Funkcjonowanie placówek spółdzielczych analizowano pod kątem struktury branżowej, rozmieszczenia oraz liczby ich i pracowników w nich zatrudnionych. Dokonano również oceny roli, jaką własne spółdzielnie odegrały w odbudowie powojennego życia ludności żydowskiej w Polsce, zarówno w sferze materialnej, jak i społecznej oraz psychologicznej, a także w rozwoju ruchu spółdzielczego w ogóle. 